\title{
The Effect of Progesterone Therapy in Severe Traumatic Brain Injury Patients on Serum Levels of s-100 $\beta$, Interleukin 6, and Aquaporin-4
}

\author{
Mahyudanil Mahyudanil $^{1 *}$, A. H. Bajamal ${ }^{2}$, R. J. Sembiring ${ }^{1}$, R. Dharmajaya ${ }^{1}$ \\ ${ }^{1}$ Department of Neurosurgery, Faculty of Medicine Universitas Sumatera Utara - Central General Hospital Haji Adam Malik \\ Medan, Indonesia; ${ }^{2}$ Department of Neurosurgery, Faculty of Medicine Airlangga University - Central General Hospital \\ Dr. Soetomo Surabaya, Indonesia
}

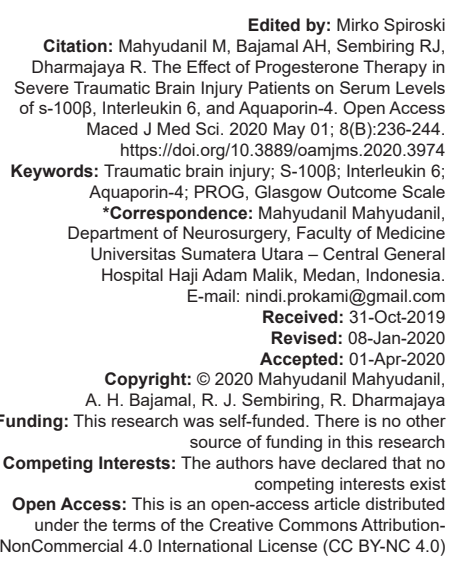

\section{Introduction}

Traumatic brain injury (TBI) is a clinical problem of neurosurgery which can cause disability, death on children, adult, and still causing economic and social problem. The incidence of TBI in USA is predicted on 1.6 million cases/year with the mortality rate is 52.000 and neurological disability on 70.000-90.000 cases. The prevalence in European continent is 708.954 cases/ year with the incidence of $235 / 100.000$ cases, and mortality of $15 / 100.000$ cases among TBI [1].

In Indonesia, TBI is caused of disability in daily activity. The incident rate became increased every year from $8.2 \%$ in 2013 to be $9.2 \%$ in 2018 . The highest prevalence rate of TBI was on age over 15-24 years old $(12.2 \%)$, male $(11 \%)$ and rural area $(9.4 \%)$. Road traffic accident still counted high proportion (31.4\%) but tend to low according to the previous report in year 2013 (42.8\%). Riding a motor cycle is high caused TBI $(72.7 \%)$ and male $(80.9 \%)$, respectively [2].

Traumatic brain injury (TBI) can cause brain tissue injury which is classified as direct injury (primary injury) and extension of late injury (secondary injury). Primary brain injury is caused by mechanical force which causing injury on brain directly after trauma (blast, laceration, bruising, hematoma, and bleeding). This can be caused by local, multifocal or diffuse injury on neuron, axon, glia, and vessels. The pathology changes on computerized tomography (CT) scan are epidural hematoma, subdural hematoma, intracerebral hemorrhage, diffuse axonal injury. and others [3].

Brain contusion is the injury of brain after the primary and secondary brain injury. Contusion consists of two zones, the central zone, and the pericontusion zone. On central zone, the necrotic event is irreversible, rupture of blood-brain barrier (BBB) and neurological cell death occurred [1], [3].

The research on biochemical marker and neuroprotective drug is based on finding of cellular activity on brain contusion from the acute phase is grow up nowadays. Clinical trials on TBI have concluded that marker of neuron injury S-100 $\beta$, neuroinflammation marker interleukin 6 (IL-6), and canal protein marker aquaporin-4 (AQP4) are 
expressed acutely after brain injury. The increasing expression of S-100ß, neuroinflammation marker IL-6, and canal protein AQP4 on serum positively correlate on BBB rupture. This marker on blood serum can be used as marker of pathophysiological cascade on BBB rupture and neuronal cell death in TBI. S- $100 \beta$ and IL- 6 reported as first marker of BBB rupture on TBI while AQP4 as the canal protein of water, regulator of the $\mathrm{BBB}$ integrity can cause the vasogenic and cytotoxic edema [4], [5], [6], [7], [8], [9], [10], [11], [12], [13], [14], [15], [16], [17].

PROG is known as a reproductive hormone with cellular function of regulating progestation, as preparing the uterus integrity on pregnancy. The PROG found diffusely on human neuron and has a pleiotropic function, the important neurobiological cellular function. In TBI, all mechanism of PROG cellularly is the main topic of neuroscience research nowadays [18], [19], [20], [21].

PROG role in TBI has many advantages so that can be used as a neuroprotective agent. Study in clinical trials with animals phase I and clinical phase II-III brain injury stated that the effect of PROG can protect the neuron from cellular mechanisms. The pharmacokinetic of PROG and effect of adverse reaction is safely known. PROG given from $24 \mathrm{~h}$ posttrauma can reduce brain edema. PROG can cross the BBB fast and reaching the plasma balance after $1 \mathrm{~h} \mathrm{[18],} \mathrm{[19],} \mathrm{[20],} \mathrm{[21],} \mathrm{[22],} \mathrm{[23],} \mathrm{[24],} \mathrm{[25],} \mathrm{[26],} \mathrm{[27],}$ [28], [29], [30], [31]. Thus, we decided to use PROG in treatment of severe TBI for reducing the biomarkers in serum.

\section{Materials and Methods}

\section{Study design}

This is an experimental, analytical study, with clinical trial, double-blinded, with pre- and posttest design. This study design to determine the efficacy of early intramuscular administration of PROG versus control group for treating patients with acute non-penetrating severe TBI caused by a blunt mechanism. This study also examines the correlation with or within change on both groups and the outcome Glasgow Outcome Scale (GOS) 3 months. This study is done on emergency room, intensive care unit, inpatient ward, outpatient ward, direct communication from phone, and in house visit. The duration of this study is until the sample is enough to start the study. This study is done by the researcher with the help of all of team - Resident of Neurosurgery, Nursery Department, Radiology Department, and Anesthesiology Department of Central Hospital Dr. Soetomo Surabaya, Indonesia. The trial was funded by researcher its self and no conflicts of interest.

\section{Study patients}

Eligible patients were adults $15-60$ years old, who had severe TBI due to a blunt mechanism, with a Glasgow Coma Scale (GCS) score of 4 to 8 . Patients were enrolled, if the study treatment could be initiated within $24 \mathrm{~h}$ after injury.

Patients were excluded if, before enrollment, the treatment team determined clinically that the injury sustained was non survivable (GCS 3) and the patient had bilateral dilated, unresponsive pupils; penetrating brain injury, or the patient had physiological findings of hypoxemia $\left(\mathrm{SaO}_{2}<80 \%, \mathrm{PO}_{2}<80 \%\right)$, hypotension (Systolic $<90 \mathrm{mmHg}$ ), spinal cord injury (multitrauma), or early post-traumatic epilepsy. Additional exclusion criteria are post-traumatic hyperglycemia (BS >200 mg/dl) and brain CT scan showed Marshall type IV, evacuated mass and non-evacuated mass.

Patient were drop out if patients had complicated after blood test, hyperthermia $\left(\mathrm{t}>40^{\circ} \mathrm{C}\right.$ ) before intervention, allergy to progesterone, death before day 5 , rejection the informed research, patient cannot trace the true address or family communication lately and need operative surgery during follow-up.

\section{Study of biomarkers}

Immediately after enrollment, patients were randomly assigned to examine serum level of S-100ß, AQP4, and IL-6 on both groups. All of biomarker was examine in $24 \mathrm{~h}$ (day 1) and $96 \mathrm{~h}$ (day 4). In treated group, the serum was talked before gave the intervention. All of biomarker was processed by ELISA.

\section{Study intervention}

The intervention was done randomly assigned to receive an injection ampouls containing PROG $1 \mathrm{mg} / \mathrm{kg}$ BW single dose. Randomization was performed with the use of a combination of minimization and biased-coin algorithms to avoid imbalances in sex, age, or enrollment site. Teams study followed the patients closely. Data on serious adverse events were collected throughout the duration of the study (3 months), and data on all adverse events were collected during the $1^{\text {st }}$ week. Data on clinical transgressions were collected and reported daily during hospitalization.

\section{Study outcomes}

The primary outcome was functional recovery as determined with the use of the GOS at 3 months after randomization. A GOS score of one indicates death, two indicates a vegetative state, three indicates severe disability, four indicates moderate disability, and five indicates good recovery. The index GCS score, the highest reliable GCS score documented 
before randomization. Moreover, the index $\mathrm{CT}$ scan is classified by Marshall CT classification.

\section{Statistical analysis}

Secondary data are shown as a frequency distribution and standard deviation using the descriptive statistical analysis. Normality test using KolmogorovSmirnov needed to determine the form of data distribution, as this can decide the statistic parametric used (parametric/ non-parametric). t-test comparative test used to compare the value of S-100B, IL-6, and AQP4. Pearson correlative test is used to find any correlation between S-100B, IL-6, and AQP4 with GOS 3 months. Moreover, ANOVA repeated measured test to find any correlation of changes of value between the two groups based on S-100B, IL-6, and AQP4 value. The results of the analysis are said to be significant if $p<0.05$ with a $95 \%$ confidence level. Data were analyzed using SPSS version 22.

\section{Results}

\section{Patients characteristic}

Patients were recruited from November 2011 to November 2012, with the final 3-month visit occurring by the end of November 2012. A total of 40 patients underwent randomization, with intramuscular administration of PROG initiated in 17 patients and control administered in 23 patients. One patient was excluded because they did not receive the complete evaluation for GOS 3 months. There were no meaningful protocol violations. This study is done on 39 man with age from 15 to 60 years, severe TBI with GCS of 4-8, blunt trauma with time injury of $<24 \mathrm{~h}$, and from the CT scan did not show the Marshal type IV criteria (Table 1).

This research is done on two groups. Control group is the majority with 23 subjects (59\%) and treated group with 16 subjects (41\%). The age of control group is 18 years old as the majority range $(21.7 \%)$ incidence of the accident, meanwhile on treatment group is 19 years (17.4\%), Table 1 .

\section{GCS and CT scan characteristic}

The mean value of GCS day 1 on all subjects is 5.88 (median 6) and 6.25 on day IV (median 6). The GCS mean value trends to recovery condition in both groups $(p=0.001)$.

Diffuse injury type $\mathrm{II}$ is the most radiographic finding in this study $(>50 \%)$. There was no finding of diffuse injury type IV in both groups that means MLS $>0.5 \mathrm{~cm}$ the patient will performed surgery operative.
Table 1: Baseline of characteristic (subgroup analysis)

\begin{tabular}{|c|c|c|c|c|}
\hline Characteristic & \multicolumn{2}{|c|}{ Progesterone $(n=16)$} & \multicolumn{2}{|c|}{ Control $(n=23)$} \\
\hline Age-year & \multicolumn{2}{|c|}{$\bar{x}=24.69$} & \multicolumn{2}{|c|}{$\bar{x}=23.26$} \\
\hline Median & \multicolumn{2}{|l|}{19} & \multicolumn{2}{|l|}{19.5} \\
\hline \multicolumn{5}{|l|}{ Age group - no.\% } \\
\hline$<20$ years old & \multicolumn{2}{|l|}{$8(50)$} & \multicolumn{2}{|l|}{$12(52.17)$} \\
\hline $20-40$ years old & \multicolumn{2}{|l|}{$7(43.75)$} & \multicolumn{2}{|l|}{$10(43.48)$} \\
\hline$>40$ years old & \multicolumn{2}{|l|}{$1(6.25)$} & \multicolumn{2}{|l|}{$1(4.35)$} \\
\hline Total & \multicolumn{2}{|l|}{$16(41)$} & \multicolumn{2}{|l|}{$23(59)$} \\
\hline Male sex - no. \% & \multicolumn{2}{|l|}{$16(100)$} & \multicolumn{2}{|l|}{$23(100)$} \\
\hline \multicolumn{5}{|l|}{ Cause of injury - no.\% } \\
\hline Motorcycle accident & \multicolumn{4}{|l|}{$33(84.6)$} \\
\hline Fall & \multicolumn{4}{|l|}{$6(15.4)$} \\
\hline $\begin{array}{l}\text { Glasgow Coma Scale score - no.\% } \\
4\end{array}$ & $\begin{array}{l}24 \mathrm{~h} \\
1(6.3)\end{array}$ & $\begin{array}{l}96 \mathrm{~h} \\
3(18.8)\end{array}$ & $\begin{array}{l}24 \mathrm{~h} \\
6(26.1)\end{array}$ & $\begin{array}{l}96 \mathrm{~h} \\
5(21.7)\end{array}$ \\
\hline 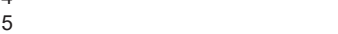 & $5(31.3)$ & $4(25.0)$ & $7(30.4)$ & $4(17.4)$ \\
\hline 6 & $6(37.5)$ & $2(12.5)$ & $4(17.4)$ & $4(17.4)$ \\
\hline 7 & $3(18.8)$ & $1(6.3)$ & $2(8.7)$ & \\
\hline 8 & $1(6.3)$ & $5(31.3)$ & $4(17.4)$ & $3(13.0)$ \\
\hline 9 & & $1(6.3)$ & & $4(17.4)$ \\
\hline 10 & & & & $2(8.7)$ \\
\hline \multirow[t]{2}{*}{12} & & & & $1(4.3)$ \\
\hline & \multicolumn{2}{|l|}{$\bar{x}=5.88$} & \multicolumn{2}{|l|}{$\bar{x}=6.25$} \\
\hline \multicolumn{5}{|l|}{ Marshall classification - no.\% } \\
\hline Type I & \multicolumn{2}{|l|}{0} & \multicolumn{2}{|l|}{$4(17.4)$} \\
\hline Type II & \multirow{2}{*}{\multicolumn{2}{|c|}{$10(62.5)$}} & \multicolumn{2}{|l|}{$12(52.2)$} \\
\hline Type III & & $6(37.5)$ & \multicolumn{2}{|l|}{$7(30.4)$} \\
\hline Type IV & \multicolumn{2}{|l|}{0} & \multicolumn{2}{|l|}{0} \\
\hline
\end{tabular}

\section{Biomarker characteristic}

There was no significant comparison $(p>0.05)$ change on serum level of S-100 $\beta$, AQP4, and IL-6, between progesterone group and control group (Table 2).

In assess subgroup analysis biomarker statue change within $24 \mathrm{~h}$ and $96 \mathrm{~h}$, we found significant value in both control (all biomarker had value $p<0.05$ ). The mean value of each biomarker will give the trend increasing or decreasing.

In study of progesterone group, we found that the mean value $\mathrm{S}-100 \beta 24 \mathrm{~h}$ is 40.57 and $96 \mathrm{~h}$ is 44.75 . $(p=0.02)$. It means that $S-100 \beta$ expression tends to increasing. The others biomarker (AQP4 and IL-6) in PROG group showed tend to increasing too $(p<0.05)$.

There was a difference in control group. S-100 $\beta$ and IL-6 serum level showed decreasing but AQP4 showed increasing $(p<0.05)$

In this subgroup analysis study, we assess correlation value of serum biomarker and the GCS $24 \mathrm{~h}$ and $96 \mathrm{~h}$. We found significant value in progesterone group $96 \mathrm{~h}$ for serum $\mathrm{S}-100 \beta$ ( $p=0.025)$, and value in control group $24 \mathrm{~h}(\mathrm{p}=0.000)$ and $96 \mathrm{~h}(\mathrm{p}=0.000)$ for serum $\mathrm{S}-100 \beta$ too.

Can serum biomarker for the first $24 \mathrm{~h}$ can predict severity of Marshall classification of CT scan. We found only IL-6 serum level had significant value in assess the correlation biomarker and CT scan $(p=0.029)$.

\section{Intervention and outcomes}

\section{Adverse events}

There was no adverse event found in this research. There was no blood or lymphatic system disorder, cardiac disorder, endocrine disorder, 


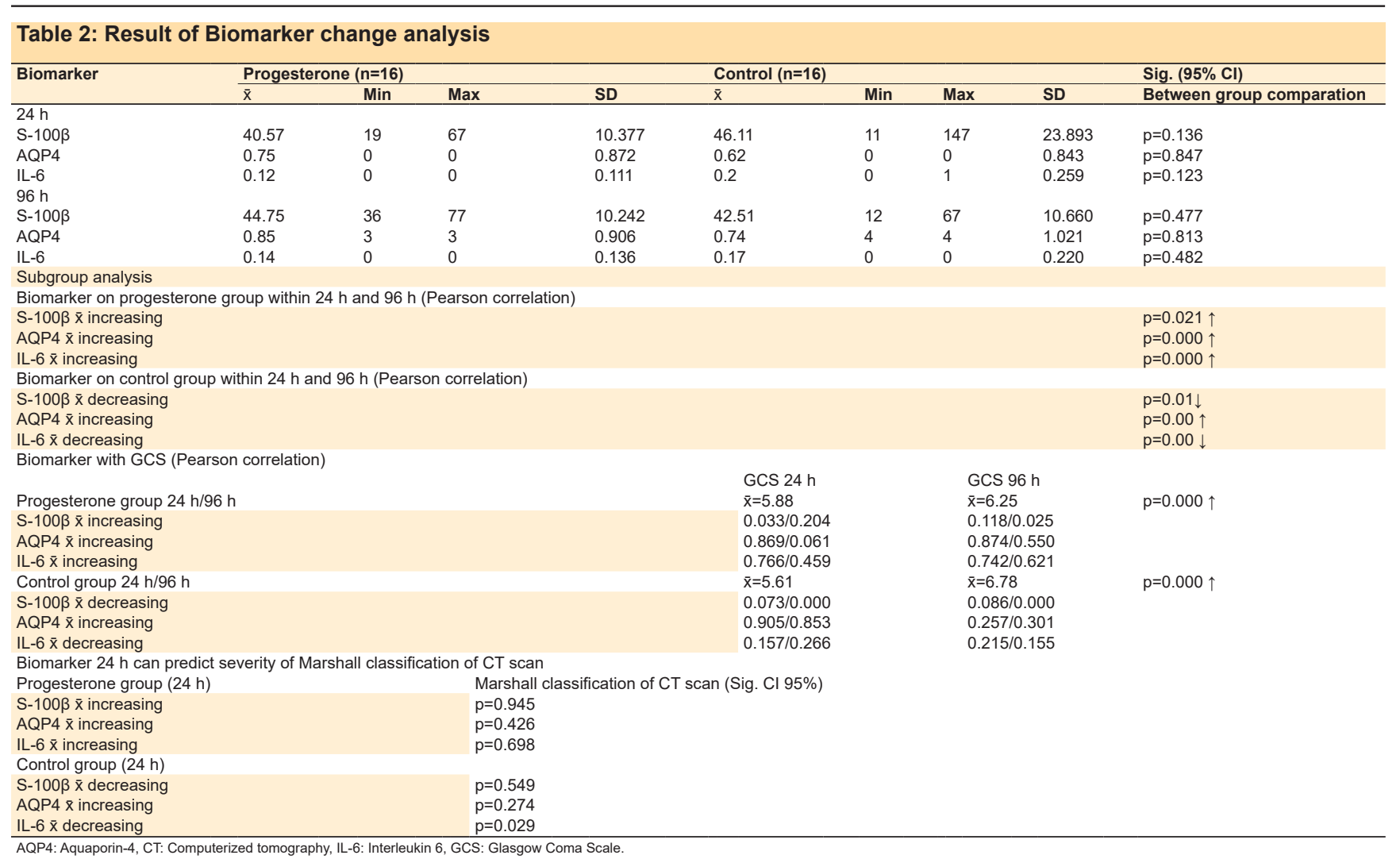

Table 3: Sliding GOS dichotomy approach

\begin{tabular}{|c|c|c|c|c|c|c|}
\hline \multirow[t]{2}{*}{ GOS 3 months } & \multicolumn{2}{|l|}{ Worst prognosis } & \multicolumn{2}{|c|}{ Intermediate prognosis } & \multicolumn{2}{|l|}{ Best prognosis } \\
\hline & Progesterone & Control & Progesterone & Control & Progesterone & Control \\
\hline Death & Unfavorable & Unfavorable & Unfavorable & Unfavorable & Unfavorable & Unfavorable \\
\hline Vegetative state & $8(50 \%)$ & $12(52.17 \%)$ & $13(81.25 \%)$ & $19(82.61 \%)$ & $16(100 \%)$ & $22(95.65 \%)$ \\
\hline Severe disability & Favorable & Favorable & Fayorable & Favorable & & \\
\hline Good recovery & $\begin{array}{l}\text { ravorable } \\
8(50 \%)\end{array}$ & $\begin{array}{l}\text { Favorable } \\
11(47.83 \%)\end{array}$ & $3(18.75 \%)$ & $4(17.39 \%)$ & $\begin{array}{l}\text { Favorable } \\
0\end{array}$ & $\begin{array}{c}\text { Favorable } \\
1(4.35 \%)\end{array}$ \\
\hline Sig. $(95 \% \mathrm{Cl})$ & $\mathrm{p}=0.285$ & & $p=0.819$ & & $p=0.827$ & \\
\hline
\end{tabular}

gastrointestinal disorder, infection, and nervous system disorder as previous warning report of progesterone side effect [32], [33].

\section{Efficacy analysis}

There was disappointed result about efficacy analysis of progesterone used in this study. Progesterone showed no significant value from control group with test comparison statistical study $(p=0.864)$ within GOS 3 months.

Next, we assess to approach by sliding dichotomy GOS as now technique (Table 3). The result showed that no difference outcome from progesterone group and control group ( $p>0.05)$.

In addition, we found in last subgroup analysis to found the serum biomarker as surrogate marker. Serum level of S-100 $\beta$ showed promising as biomarker that predicts outcome of TBI. In this study, the day 4 (96 h) in both groups showed of serum level S-100ß had significant value for predict the outcome GOS 3 months $(p=0.000)$.

\section{Discussion}

\section{Demographic characteristic}

The youngest age of this subject is 16 and the oldest is 47 and is corresponding to the inclusion criteria. The productive age is reportedly the prone group of occurrence of brain injury. This is because of mobilization of productive group and the use of motor vehicle increased rapidly in Indonesia as a developing country [2]. All the subject is man. Indirectly, the existence of men as the subject hindering the bias of information that woman with brain injury have better outcome of brain injury [23]. Women have gestational sex hormone thought that theoretically may be affect the outcome of brain injury. Menopause female patient reportedly have improved outcome in postmenopausal but not premenopausal female of outcome of brain injury [34].

\section{GCS}

The mean value of GCS day 1 on all subject is 5.72 (median 6) and 6.56 on day 4 (median 6). GCS 
Table 4: Result of efficacy analysis

\begin{tabular}{|c|c|c|c|}
\hline Outcome (GOS $3 \mathrm{mt}$ ) & Progesterone $(n=16)$ & Control $(n=23)$ & Sig. $(95 \% \mathrm{Cl})$ comparison \\
\hline Primary efficacy analysis - no.\% & $\overline{\mathrm{x}}=2.38 . \mathrm{SD}=1.147$ & $\bar{x}=2.57 . S D=1.037$ & $\mathrm{p}=0.864$ \\
\hline Dead & $5(31.3)$ & $3(13.0)$ & \\
\hline Vegetative state & $3(18.8)$ & $9(39.1)$ & \\
\hline Severe Disability & $5(31.3)$ & $7(30.4)$ & \\
\hline Moderate disability & $3(18.8)$ & $3(13.0)$ & \\
\hline Good recovery & 0 & $1(4.3)$ & \\
\hline \multicolumn{4}{|l|}{ Subgroup analysis } \\
\hline \multicolumn{4}{|l|}{ Biomarker - GOS prediction } \\
\hline Progesterone Group & $24 \mathrm{~h}$ Sig. $(\mathrm{Cl}=95 \%)$ & 96 h Sig. $(\mathrm{Cl}=95 \%)$ & \\
\hline S-100 $\bar{x}$ decreasing & $\mathrm{p}=0.206$ & $p=0.000$ & \\
\hline AQP4 $\bar{x}$ increasing & $p=0.217$ & $p=0.172$ & \\
\hline IL-6 $\bar{x}$ decreasing & $p=0.225$ & $p=0.290$ & \\
\hline \multicolumn{4}{|l|}{ Control group } \\
\hline$S-100 \beta \bar{x}$ increasing & $p=0.021$ & $p=0.000$ & \\
\hline AQP4 $\bar{x}$ increasing & $\mathrm{p}=0.928$ & $p=0.211$ & \\
\hline IL-6 $\bar{x}$ increasing & $p=0.212$ & $p=0.114$ & \\
\hline
\end{tabular}

of all subjects is GCS 5 on day 1 and GCS 8 on day 4. This research showed recovery GCS in all subject according to assess mean difference, however the overall outcome showed no significance. GCS is still used as an indicator to predict the severity of and the prognostic of severe TBI [35].

\section{CT scan characteristic}

Brain CT scan is still considered as gold standard diagnosis of severe TBI. Marshall created criteria of CT scan as an imaging of neural injury on severe TBI. Cerebral edema can be shown on brain CT scan with type I-IV. In type IV with presented midline shift $>5 \mathrm{~mm}$ always facing the surgical indication with excluding cases in this research [36].

Cerebral edema is the main topic of this study, S-100ß, IL-6, and AQP4 reportedly used as a marker of BBB rupture [5], [8], [10], [15], [17] BBB rupture on cerebral edema causing the release biochemical marker to the systemic. BBB rupture and neural injury on $\mathrm{TBI}$ cannot be distinguished from the cerebral edema [14]. However, in this research showed only the increasing of serum IL-6 that explained in severe TBI often increasing intracranial pressure (ICP) that more sensitive by IL- 6 change [8]. The first limitation of this research is no examination or data collected about the ICP.

\section{S100ß, AQP4, and IL-6 on treatment group}

The result of this study showed increasing value of blood serum of S-100 $\beta$ and IL- 6 but increasing serum of AQP4 after the administration of PROG $1 \mathrm{mg} /$ $\mathrm{kg} B W$ intramuscular single doses. The change serum level probably the dosage was suboptimal.

The mean value of three biomarker in PROG group showed tends to increasing on S-100 $\beta$, IL-6 and AQP4. The same dynamic change only showed AQP4 increasing in both groups. This mechanism may be explained PROG as inhibitors of AQP-4 stimulate S-100 $\beta$ secretion in acute severe TBI [16].

\section{Biomarker and GOS in severe TBI}

This study showed significance correlation of serum level S-100 $\beta$ day 4 (96 h) in both groups that predict the outcome GOS 3 months. In acute dynamic condition (day 1 until day 3 ) of severe, TBI may be the process have high complexity. There was a another extracranial injury that involves bias or change in S-100 $\beta$ serum level [37], [38], [39].

Based on Korfias et al., the degree of severity of the patients shows different expression of S-100 $\beta$ [40]. After 20 years, S-100 $\beta$ suggests as a prognostic indicator on research of brain injury, brain ischemic, and drug study that have a potential value of increasing person life expectancy in brain trauma patient [6], [7], [38], [40]

\section{Clinical outcomes}

The primary endpoint, the GOS score at 3 months, did not differ significantly between the PROG group and the control group (Tables 3 and 4). The proportional-odds model revealed no effect of PROG treatment in either unadjusted or adjusted analyses by sliding dichotomy approach. The proportion of patients with an overall favorable outcome (good recovery or moderate disability) on the GOS was $18.75 \%$ in the PROG group and $17.9 \%$ in the control group. The proportion of patients who were in a vegetative state or who died was also similar in the two groups: $81.25 \%$ in the PROG group and $82.61 \%$ in the control group. This research results do not support the hypothesized superiority of PROG treatment over treated group in patients with severe TBI, as assessed by means of the GOS or approach to sliding GOS dichotomy [32].

The other investigation of eight randomized controlled trials meta-analysis in PROG administration improves the clinical outcomes of severe TBI patients within 3 months post-injury but may not have significant long-term benefits at 6 months post-injury [33].

\section{Heterogeneity: Single bullet versus multitarget therapy}

The long history of failed TBI trials, including the current trial, is probably due to several factors, including 
the complexity and variability of the injury and the fact that multiple direct and indirect injury mechanisms are at work simultaneously [32], [41], [42].

TBI is a complex disease and has a pathology process, heterogeneous disorder, in which the primary injury initiates a variety of secondary injury cascades. These cascades involve various processes that may not be responsive to monotherapy (single bullet), as has been shown by the failure of previously studied monotherapies that have targeted single receptors or specific mechanisms, despite considerable supportive experimental data. Systemic and extraneuronal effects of trauma also require consideration with respect to their effect on mortality among patients with TBI [32], [42].

These complex injury mechanisms suggest that a successful therapeutic agent should influence several mechanisms rather than a single cascade. On the basis of the experimental data, PROG would appear to be an appropriate candidate for this multipotential role, having been shown to prevent inflammation by inhibiting the production of inflammatory cytokines (e.g., tumor necrosis factor- $\alpha$ ), as well as by reducing levels of inflammation-related factors such as complement factor C3 fragments and inhibiting the activation of microglial cells. In addition PROG has been shown to prevent excitotoxicity and limits apoptosis by preventing biochemical insults, such as calcium $\left(\mathrm{Ca}^{2}+\right)$ flux and nitric oxide production, and by decreasing levels of caspase 3. Finally, PROG has also been shown to limit vasogenic edema through reconstitution of the $B B B$ and modulation of the AQP4 water transporter [32], [41].

\section{Dosage adjusted and solubility}

This study used the administration of PROG $1 \mathrm{mg} / \mathrm{kg}$ BW intramuscular single doses. In this research, the choosing of maintenance dose as Xiao publication in China had not been done because there was no absolute recommendation on dosage and delivery technique on research report before.

The analysis stratified by administration route showed that beneficial effects were only observed in patients who received PROG intramuscularly [33]. Preliminary clinical data obtained with the use of various PROG formulations and routes of delivery, combined with experimental data showing adequate brain penetration, provided initial support for a neuroprotective role of PROG in TBI. The initial PROTECT trial recruited 100 patients from a single site who had a GCS score of 4-12. Treatment was initiated within $11 \mathrm{~h}$ after injury, with a 72-h treatment duration, and was associated with a reduction in the rate of death from any cause, as compared with placebo. A similar single-site trial in China recruited 159 patients who had a GCS score of 8 or lower. PROG treatment, which was initiated within $8 \mathrm{~h}$ after injury by means of intramuscular injection, with a 120-h treatment duration, was associated with reduced mortality, as compared with placebo [32].
Drug dose and delivery route are important parameters that influence clinical efficacy. Of the included trials, PROG was administered intravenously in three studies and intramuscularly in four. One study gave a medroxyprogesterone tablet through nasogastric tube. Our analysis showed that PROG only conferred neuroprotection in patients who were given PROG intramuscularly. The discrepancy in the efficacies of intravenous and intramuscular administration is unclear [33].

When we evaluated the pharmacological profile of the presentations tested for clinical efficacy, most of the available drugs are poorly acidic or poorly basic and have low aqueous solubility. These poorly soluble drugs in water evolve with low absorption rates, which can result in low tissue bioavailability, being critical for their rapid and effective action, as in brain injury. The solubility dilemma is a major challenge for its formulation. Solubility is an important parameter in obtaining drugs with the ability to achieve the desired concentration in the brain and other tissues [43].

Due to progesterone's plasma half-life of only $25 \mathrm{~min}$, it is necessary to take it to the brain rapidly which in practical conditions would require immediate continuous IV post-trauma treatment. It can be stated that the dripping or use of multiple injections in a lipidbased vehicle delays the release into the systemic circulation and results in a consequent reduction of the expected protective properties of PROG in the acute phase of TBI. This feature is important and makes it difficult to "replicate" the compelling results obtained in pre-clinical trials in guinea pigs [43].

\section{Insensitivity of the outcome measures}

However, recovery from severe $\mathrm{TBI}$ is a slow gradual process, mortality and GOS score are not sufficiently sensitive to quantitatively measure functional deficits and gradual recovery over time [33]. There may also be insensitivity of the available outcome measures [32], [44], [42].

The lack of mechanistic early endpoints and the absence of reliable biomarkers to guide clinical development and inform clinical-trial design may be considered to be major obstacles to the development of neuroprotective agents for TBI. In addition, current approaches to the characterization of TBI are mainly unidimensional (based on GCS scores or Marshall classification) and do not permit appropriately targeted therapy. Multidimensional approaches are needed for better characterization of TBI to facilitate individualized treatment [32], [42], [44],

\section{Future animal study}

PROG has been shown to have broad neuroprotective properties in multiple animal species 
and in a variety of models of neurologic injury. Multifactorial effects of PROG include inhibition of inflammatory cytokines, reduced levels of inflammationrelated factors, prevention of excitotoxicity, reduction of apoptosis, and control of vasogenic edema.

The PROG receptor plays a key role in these neuroprotective effects. A total of 20 research groups working with four species and 22 different models have found neuroprotective effects of PROG in more than 180 experimental pharmacologic studies. In addition, two phase II randomized, controlled clinical trials with PROG showed a clinical benefit. On the basis of these collective data, two phase III trials were initiated at around the same time: The study of a neuroprotective agent, PROG, in severe TBI (SYNAPSE), and the PROG for the treatment of TBI (PROTECT III) trial. SYNAPSE, a trial sponsored by BHR Pharma, was designed to investigate the clinical effectiveness of PROG, provided in a $6 \%$ soybean oil emulsion as a ready-touse formulation, under well-controlled conditions. The PROTECT III trial, funded by the National Institutes of Health, was conducted in parallel, but the study was halted on the basis of a futility analysis performed after 882 patients had undergone randomization.

In conclusion, PROG as administered in this trial had no clinical benefit in the treatment of severe TBI. The negative result of this study should stimulate a rethinking of procedures for drug development and testing in TBI.

Limitations in the ability to translate experimental data to the context of TBI in humans may also have contributed to the trial failures. A more systematic approach appears to be necessary to advance therapeutics in TBI.

\section{Endogenous Progesterone}

Stein DG, 2016 said that the clinical phase III of PROG has no effect of improvement in TBI patients as in control population, this can be caused from: Heterogenecity, the different definition of brain trauma, the needs of thorough study on animal study, use of other sensitive biomarker from serum and inflammation cascade, the report of data and the chance of no sensitivity of outcome scale result [42].

As an addendum, the cause of failure from this study can be caused no examination of endogenous level of progesterone. Because of progesterone is in cell nucleus, thus needed more thorough study of mechanism of PROG from the pharmacokinetic to pharmacodynamic so that can be shown what disrupt the pathway of pharmacokinetic and pharmacodynamics of PROG itself [45].

PROG concentration changes according to age. The highest concentration of PROG is in neonates, and in 1-12 months children, the value is decreasing $1 / 3$ times from the neonate. Genazzini et al. in 1998 found that PROG value decreased from 19 until over 60 years. Davis et al. study reported that the identical pattern of improved outcomes in postmenopausal but not premenopausal females versus age-matched males was observed. However, Davis et al. reported that endogenous female sex hormone production is not neuroprotective [34].

In humans, PROG levels in both the plasma and CSF rapidly and transiently increase after severe TBI possibly as part of the endogenous protective response. The addition of exogenous PROG may augment the physiological neuroprotective [43]. Further research is yet to be done to assess the pharmacological effect of PROG.

\section{Conclusion}

S-100 $\beta$ serum levels can be used as surrogate marker for TBI prognosis in clinical research especially new potential drug. Serum S-100 $\beta$ is significant enough to predict the outcome of severe TBI.

Progesterone effect on severe TBI patient with biomarker testing still had unclearly concept theory in repairing neuronal injury and/or BBB disruption. The other consideration is about concept theory of temporal trajectory S100ß, AQP4, and IL-6 in serum level after TBI.

For the future study, suggestion is necessary to investigation endogenous PROG naturally especially in TBI. Introducing serum biomarkers such as S-100 $\beta$ in future pharmaceutical trials may be possible to better monitoring the effect of specific pharmacological treatments.

\section{Ethical Clearance}

Research approval was obtained from the Ethics Committee of the Medical Faculty, University of Airlangga - Central Hospital Dr. Soetomo, East Java, Indonesia. Every research subject has the right to know the results of the examination conducted on him.

\section{References}

1. Engel DC. Secondary Damage After Traumatic Brain Injury: Epidemiology, Pathophysiology and Therapy. Rotterdam: Erasmus Universiteit; 2008.

2. RISKESDAS. Indonesia Ministry of Health, Health Research 
and Development. Jakarta, Indonesia: Indonesia Ministry of Health; 2018.

3. Reilly PR, Selladurai BE. Pathophysiology of acute non missile head injury. In: Initial Management of Head Injury, a Comprehensive Guide. Australia: McGraw-Hill Australia Pty Limited.; 2007. p. 10-32.

4. Rothermundt M, Ponath G, Glaser T, Hetzel G, Arolt V. S-100B serum levels and long-term improvement of negative symptoms in patients with schizophrenia. Neuropsychopharmacology. 2004;29(5):1004-11. https://doi.org/10.1038/sj.npp.1300403 PMid:14997170

5. Kleindienst A, Ross Bullock M. A critical analysis of the role of the neurotrophic protein $\mathrm{S}-100 \mathrm{~B}$ in acute brain injury. J Neurotrauma. 2006;23(8):1185-200. https://doi.org/10.1089/ neu.2006.23.1185

PMid:16928177

6. Tala MI, Darmadipura S. Hubungan Perubahan Kadar Protein S-100ß Dalam Cairan Serebrospinalis Dengan Tingkat Kesadaran Pasien Cedera Otak Berat. Karya Akhir S2 Skripsi. Surabaya, Indonesia: Airlangga University-School of Medicine; 2008.

7. Ndraha E, Bajamal AH. Hubungan Antara Perubahan Kadar S-100ß Pada Pasien Cedera Kepala Berat Pada Fase Akut Dengan Outcome. Karya Akhir S2 Skripsi. Surabaya, Indonesia: Airlangga University-School of Medicine; 2010.

8. Hergenroeder GW, Moore AN, McCoy JP, Samsel L, Ward NH, Clifton GL, et al. Serum II-6: a candidate biomarker for intracranial presure elevation following isolated traumatic brain injury. J Neuroinflammation. 2010;7:19. https://doi. org/10.1186/1742-2094-7-19

PMid:20222971

9. Verkman AS. Aquaporins: Translating bench research to human disease. J Exp Biol. 2008;212(Pt 11):1707-15. https://doi. org/10.1242/jeb.024125

PMid: 19448080

10. Oliviera CO, Ikuta $\mathrm{N}$, Regner A. Outcome biomarker following severe traumatic injury. Rev Bras Ter Intensiva. 2008;20(4):411-21.

PMid:25307248

11. Raheja A, Sinha S, Samson N, Bhoi S, Subramanian, A, Sharma $\mathrm{P}$, et al. Serum biomarkers as predictors of long-term outcome in severe traumatic brain injury: Analysis from a randomized placebo-controlled Phase II clinical trial. J Neurosurg. 2016;125(3):631-41. https://doi.org/10.3171/2015.6.jns15674 PMid:26722854

12. Van Landingham JW, Cutler SM, Cekik M, Wright D, Stein DG. Serum biomarker profiling for progesterone treatment of traumatic brain injury: A comparative study human and rat. FASEB J. 2006;20:1314-25.

13. Thelin EP, Zeiler FA, Ercole A, Mondello S, Büki A, Bellander B, et al. Serial sampling of serum protein biomarkers for monitoring human traumatic brain injury dynamics: A systematic review. Front Neurol. 2017;8:300. https://doi.org/10.3389/ fneur.2017.00300

PMid:28717351

14. Thelin EP, Nimer FA, Frostell A, Zetterberg H, Blennow $\mathrm{K}$, Nystrom $\mathrm{H}$, et al. A serum protein biomarker panel improves outcome prediction in human traumatic brain injury. J Neurotrauma. 2019;36(20):2850-62. https://doi.org/10.1089/ neu.2019.6375

PMid:31072225

15. Miao X, Wei S, Qiu-Ping X. Aquaporin-4 and traumatic brain edema. Chin J Traumatol. 2010;13(2):103-10.

PMid:20356447

16. Zanotto C, Abib RT, Batassini C, Tortorelli LS, Biasibetti R,
Nardin LR, et al. Non-specific inhibitors of aquaporin-4 stimulate S-100B secretion in acute hippocampal slices of rats. Brain Res. 2013;1491:14-22. https://doi.org/10.1016/j. brainres.2012.10.065

PMid:23142267

17. Thelin EP, Nelson DW, Bellander BM. A review of the clinical utility of serum S-100B protein levels in the assessment of traumatic brain injury. Acta Neurochir. 2017;159:209-25. https:// doi.org/10.1007/s00701-016-3046-3

PMid:27957604

18. Cutler SM. The Effect of Progesterone Withdrawal on Behavioral and Molecular Indices after Traumatic Brain Injury, PhD Thesis. Georgia: Georgia Institute of Technology; 2005.

19. Cutler SM, Milos C, Miller DM, Wali B, Vanlandingham JW, Stein DG. Progesterone improves acute recovery after traumatic brain injury in the aged rat. J Neurotrauma. 2007;24:1475-86. https://doi.org/10.1089/neu.2007.0294 PMid:17892409

20. Schumacher M, Guennoun R, Ghoumari A, Massaad C, Robert F. Novel perspectives for progesterone in hormone replacement therapy, with special reference to the nervous system. Endocr Rev. 2007;28(4):387-439. https://doi. org/10.1210/er.2006-0050

PMid: 17431228

21. Stein DG. Progesterone exerts neuroprotective effects after brain injury. Brain Res Rev. 2008;57:386-97. https://doi. org/10.1016/j.brainresrev.2007.06.012

PMid:17826842

22. Stein DG, Wright DW, Kellermann AL. Does progesterone have neuroprotective properties? Ann Emerg Med. 2008;51(2):16472. https://doi.org/10.1016/j.annemergmed.2007.05.001 PMid: 17588708

23. Farace E, Alves WM. Do women fare worse? A metaanalysis of gender differences in outcome after traumatic brain injury. J Neurosurg. 2000;93(4):539-45. https://doi.org/10.3171/ jns.2000.93.4.0539

PMid:11014529

24. Wright DW, Bauer ME, Hoffman SW, Stein DG. Serum progesterone levels correlate with decreased cerebral edema after traumatic brain injury in male rats. J Neurotrauma. 2001;18(9):901-9. https://doi. org/10.1089/089771501750451820

PMid:11565602

25. Djebaili M, Guo Q, Pettus EH, Hoffman SW, Stein DG. The neurosteroids progesterone and allopregnanolone reduce cell death, gliosis, and functional deficits after traumatic brain injury in rats. J Neurotrauma. 2005;22(1):106-18. https://doi. org/10.1089/neu.2005.22.106

PMid:15665606

26. YaoXL, Liu J, Lee E, Ling GS, Mccabe JT. Progesterone differentially regulates pro and anti-apoptotic gene expression in cerebral cortex following traumatic brain injury in rats. J Neurotrauma. 2005;22(6):656-68. https://doi.org/10.1089/neu.2005.22.656 PMid: 15941375

27. Chen G, Shi J, Ding Y, Yin H, Hang C. Progesterone prevents traumatic brain injury-induced intestinal nuclear factor kappa b activation and proinflammatory cytokines expression in male rats. Mediators Inflamm. 2007;2007:93431. https://doi. org/10.1155/2007/93431

PMid: 18274644

28. Wright DW, Kellermann AL, Hertzberg VS, Clark PL, Frankel M. proTECT: A randomized clinical trial of Progesterone for acute traumatic brain injury. Ann Emerg Med. 2006;20(10):1-13.

29. Gibson CL, Gray LJ, Bath PM, Murphy SP. Progesterone for the treatment of experimental brain injury; a systematic review. 
Brain. 2008;31:318-28. https://doi.org/10.1093/brain/awm183 PMid:17715141

30. Gibson CL, Coomber B, Rathbone J. Is Progesterone a candidate neuroprotective factor for treatment following ischemic stroke? Neuroscientist. 2009;15(4):324-32. https://doi. org/10.1177/1073858409333069

PMid:19359672

31. Xiao G, Wei J, Yan W, Wang W, Lu Z. Improved outcomes from the administration of progesterone for patients with acute severe traumatic brain injury: A randomized controlled trial. Crit Care. 2008;12(2):R61. https://doi.org/10.1186/cc6887 PMid: 18447940

32. Skolnick BE, Maas Al, Narayan RK, van der Hoop RG, MacAllister T, Ward JD, et al. A clinical trial of progesterone for severe traumatic brain injury. N Engl J Med. 2014;371(26):246776. https://doi.org/10.1056/nejmoa1411090 PMid:25493978

33. Pan ZY, Zhao YH, Huang WH, Xiao ZZ, Li ZQ. Effect of progesterone administration on the prognosis of patients with severe traumatic brain injury: A meta-analysis of randomized clinical trials. Drug Des Dev Ther. 2019;13:265-73. https://doi. org/10.2147/dddt.s192633 PMid:30666088

34. Davis DP, Douglas JD, Smith DW, Sisegary M, Troy LV, Kennedy A, et al. Post-menopausal females versus agematched males. J Neurotrauma. 2006;23(2):140-8.

PMid: 16503798

35. Chesnut RM, Ghajar J, Maas Al, Marion DW, Servadei F. Early indicators of prognosis in severe traumatic injury. In: Part II Management and Prognosis of Severe Traumatic Injury. A Joint project of Brain Trauma Foundation. New York: American Association of Neurological Surgeon, Joint section of Neurotrauma and Critical Care, Brain Trauma Foundation; 2003. https://doi.org/10.1089/neu.2000.17.555

36. Cooper PR. Post traumatic intracranial mass lesion. In: Cooper PR, editor. Head Injury. Baltimore: Williams and Wilkins; 1993. p. 275-330

37. Benjamin A, Matthew L, Hitomi, E, Peng W, Liao Y, Lou N, et al. Biomarkers of traumatic injury are transported from brain to blood via the glymphatic system. J Neurosci. 2015;35(2):51826. https://doi.org/10.1523/jneurosci.3742-14.2015

\section{PMid:25589747}

38. Thelin EP, Nelson DW, Bellander BM. A review of the clinical utility of serum S100B protein levels in the assessment of traumatic brain injury. Acta Neurochir. 2017;159(2):209-25. https://doi.org/10.1007/s00701-016-3046-3 PMid:27957604

39. Pham N, Fazio V, Cucullo L, Teng Q, Biberthaler P, Bazarian JJ, et al. Extracranial Sources of S100B Do Not Affect Serum Levels. PLoS One. 2010;5(9):e12691. https://doi.org/10.1371/ journal.pone. 0012691 PMid:20844757

40. Korfias S, Stranjalis G, Papadimitriou A, Psachoulia C, Daskalakis G. Antsaklis A, et al. Serum S-100B protein as a biochemical marker of brain injury: A review of current concept. Curr Med Chem. 2006;13(30):3719-31. https://doi. org/10.2174/092986706779026129

PMid:17168733

41. Wei J, Xiao GM. The neuroprotective effects of progesterone on traumatic brain injury: current status and future prospects. Acta Pharmacol Sin. 2013;34(12):1485-90. https://doi.org/10.1038/ aps.2013.160 PMid:24241345

42. Stein DG. Embracing failure: What the Phase III progesterone studies can teach about TBI clinical trials. Brain Inj. 2015;29(11):1259-72. https://doi.org/10.3109/02699052.2015.1 065344

PMid:26274493

43. Eduardo OD, Luciano MP. Medical theory: Why does progesterone not work after a traumatic brain injury in humans? Am J Biomed Sci Res. 2019;5(4):929.

44. Wright DW, Yeatts SD, Silbergleit R, Palesch YY, Hertzberg VS, Frankel $\mathrm{M}$, et al. Very early administration of progesterone for acute traumatic brain injury. N Engl J Med. 2014;371(26):245766. https://doi.org/10.1056/nejmoa1404304 PMid:25493974

45. Zhu X, Frechou M, Liere P, Zhang S, Pianos A, Fernandez N, et al. A role of endogenous progesterone in stroke cerebroprotection revealed by the neural-specific deletion of its intracellular receptors. J Neurosci. 2017;37(45):10998-1020. https://doi. org/10.1523/jneurosci.3874-16.2017

PMid:28986464 